\title{
NEW HIGH VOLTAGE CATHODE MATERIALS FOR RECHARGEABLE LITHIUM BATTERIES
}

\author{
GEORGE TING-KUO FEY \\ Department of Chemical Engineering, National Central University, Chung-Li, Taiwan \\ 32054, Republic of China
}

(Received November 20, 1994; in final form November 30, 1994)

\section{INTRODUCTION}

Since the $\mathrm{LiCoO}_{2} / \mathrm{Li}_{x} \mathrm{C}_{6}$ "lithium-ion cell" was introduced into the consumer market by Sony Energytec, Inc. of Japan in 1990 [1], lithium secondary batteries have regained consumer confidence due to their improved long cycle life and safe cell operation. These improvements in cell performance are achieved at the expense of energy density by replacing the metallic lithium anode with an intercalation electrode material, usually a carbon. To compensate for the loss in energy density, the working voltage of the cathode in lithium-ion cells is required to be very high, preferably about $4 \mathrm{~V}$ during discharging.

To this date, three major systems of high voltage cathode materials have been developed and marketed for lithium-ion cells: (1) $\mathrm{LiCoO}_{2}$ by Sony Energytec, Inc., (2) $\mathrm{LiNiO}_{2}$ by Moli Energy (1990) Ltd., and (3) $\mathrm{LiMn}_{2} \mathrm{O}_{4}$ by Bellcore. Both $\mathrm{LiCoO}_{2}$ and $\mathrm{LiNiO}_{2}$ have a layered structure whereas $\mathrm{LiMn}_{2} \mathrm{O}_{4}$ has a spinel structure. The upper voltage limits of these cathode materials are in the 4.3-4.5 V range where most of the lithium ions can be electrochemically removed, resulting in a high specific energy.

In the context of this article, high voltage cathode will refer to those cathodes that require charging above $4 \mathrm{~V}$ vs. Li. Typical examples are the lithiated transition metal oxides mentioned above. In contrast, low voltage cathodes composed of materials such as $\mathrm{TiS}_{2}[2-3], \mathrm{MoS}_{2}$ [4], $\mathrm{MoO}_{3}[5,6], \mathrm{NbSe}_{3}$ [7-8], $\mathrm{MnO}_{2}$ [9], and vanadium oxides $[5,10-11]$, are fully charged well below $4 \mathrm{~V}$.

In 1993, we discovered that $\mathrm{LiNiVO}_{4}$ can be a high voltage cathode material for lithium secondary cells [12]. Our finding is significant because $\mathrm{LiNiVO}_{4}$ not only exhibits a voltage of 4.8 volt, the highest observed for any known $\mathrm{Li}$ intercalation reaction, but is also the first material with an inverse spinel structure to be used as a cathode for rechargeable lithium cells. Further applications to thin-film cells and lithium-ion cells are feasible provided that a proper electrolyte stable to high oxidation potential can be developed.

In this paper, new preparation methods for $\mathrm{LiNiVO}_{4}$ and its isostructural compound $\mathrm{LiCoVO}_{4}$ [13] will be reported and the effects of starting materials, reactant stoichiometry, synthesis temperature, and reaction environment on the quarternary $\mathrm{Li}-\mathrm{Ni}-\mathrm{V}-\mathrm{O}$ reaction will be discussed. In addition, the results from 
TABLE 1

Preparation Methods and Reaction Conditions for $\mathrm{LiMVO}_{4}$ Compounds

\begin{tabular}{|c|c|c|c|}
\hline Compound & Reactants & Reaction Condition & Ref. \\
\hline $\mathrm{LiCoVO}_{4}$ & $\begin{array}{l}\mathrm{LiVO}_{3}+\mathrm{CoC}_{2} \mathrm{O}_{4} \\
\mathrm{LiCoO}_{2}+\mathrm{V}_{2} \mathrm{O}_{3} \\
\mathrm{LiCoO}_{2}+\mathrm{V}_{2} \mathrm{O}_{5} \\
\end{array}$ & $\begin{array}{l}500^{\circ} \mathrm{C}, 7 \text { days } \\
700^{\circ} \mathrm{C}, 1 \mathrm{~h} \\
700^{\circ} \mathrm{C}, 1 \mathrm{~h} \\
\end{array}$ & $\begin{array}{l}19 \\
12 \\
13 \\
\end{array}$ \\
\hline $\mathrm{LiNiVO}_{4}$ & $\begin{array}{l}\mathrm{LiVO}_{3}+\mathrm{NiCO}_{3} \\
\mathrm{Li}_{2} \mathrm{O}+\mathrm{NiO}+\mathrm{V}_{2} \mathrm{O}_{5} \\
\mathrm{LiNiO}_{2}+\mathrm{V}_{2} \mathrm{O}_{3} \\
\mathrm{LiNiO}_{2}+\mathrm{V}_{2} \mathrm{O}_{5}\end{array}$ & $\begin{array}{l}500^{\circ} \mathrm{C}, 7 \text { days } \\
800^{\circ} \mathrm{C}, 1 \text { day to } 500^{\circ} \mathrm{C}, 25 \text { days } \\
500^{\circ} \mathrm{C}, 4 \mathrm{~h} \text { and } 800^{\circ} \mathrm{C}, 6 \mathrm{~h} \\
700^{\circ} \mathrm{C}, 2 \mathrm{~h}\end{array}$ & $\begin{array}{l}19 \\
20 \\
21 \\
13\end{array}$ \\
\hline $\mathrm{LiCuVO}_{4}$ & $\mathrm{Li}_{2} \mathrm{CO}_{3}+\mathrm{CuO}+\mathrm{V}_{2} \mathrm{O}_{5}$ & $530^{\circ} \mathrm{C}$ & 22 \\
\hline $\mathrm{LiMgVO}_{4}$ & $\begin{array}{l}\mathrm{Li}_{2} \mathrm{CO}_{3}+\mathrm{MgO}+\mathrm{NH}_{4} \mathrm{VO}_{3} \\
\mathrm{Li}_{2} \mathrm{CO}_{3}+\mathrm{MgCO}_{3}+\mathrm{NH}_{4} \mathrm{VO}_{3} \\
\mathrm{Li}_{2} \mathrm{O}+\mathrm{MgO}+\mathrm{V}_{2} \mathrm{O}_{5}\end{array}$ & $\begin{array}{l}650^{\circ} \mathrm{C}, 4 \text { days } \\
750^{\circ} \mathrm{C}, 1 \text { day } \\
800^{\circ} \mathrm{C}, 1 \text { day to } 500^{\circ} \mathrm{C}, 25 \text { days }\end{array}$ & $\begin{array}{l}17 \\
18 \\
20 \\
\end{array}$ \\
\hline $\mathrm{LiCdVO}_{4}$ & $\mathrm{Li}_{2} \mathrm{CO}_{3}+\mathrm{CdCO}_{3}+\mathrm{NH}_{4} \mathrm{VO}_{3}$ & $600^{\circ} \mathrm{C}, 8$ days & 17 \\
\hline $\mathrm{LiBeVO}_{4}$ & $\mathrm{Li}_{2} \mathrm{CO}_{3}+\mathrm{BeO}+\mathrm{NH}_{4} \mathrm{VO}_{3}$ & $750^{\circ} \mathrm{C}, 1$ day & 18 \\
\hline $\mathrm{LiZnVO}_{4}$ & $\begin{array}{l}\mathrm{Li}_{2} \mathrm{CO}_{3}+\mathrm{ZnO}+\mathrm{NH}_{4} \mathrm{VO}_{3} \\
\mathrm{Li}_{2} \mathrm{O}+\mathrm{ZnO}+\mathrm{V}_{2} \mathrm{O}_{5} \\
\mathrm{Li}_{2} \mathrm{CO}_{3}+\mathrm{ZnO}+\mathrm{V}_{2} \mathrm{O}_{5}\end{array}$ & $\begin{array}{l}750^{\circ} \mathrm{C}, 1 \text { day } \\
800^{\circ} \mathrm{C}, 1 \text { day to } 500^{\circ} \mathrm{C}, 25 \text { days } \\
500^{\circ}-700^{\circ} \mathrm{C}\end{array}$ & $\begin{array}{l}18 \\
20 \\
23\end{array}$ \\
\hline
\end{tabular}

characterization, structural analysis, and cell performance of these new materials will also be presented.

\section{MATERIAL BACKGROUND AND PREPARATION}

As early as the 1950s and 1960s, $\mathrm{LiMVO}_{4}$ materials, where $\mathrm{M}=\mathrm{Cu}$ [14], $\mathrm{Ni}$ [15], $\mathrm{Co}$ [15], Zn [16], Cd [17], Mg [18], Be [18], etc., have been studied with an emphasis on their preparation and characterization. In general, the traditional method of solid state reaction at high temperature is employed for the preparation of $\mathrm{LiMVO}_{4}$ compounds, by mixing and heating stoichiometric amounts of lithium carbonate, ammonium vanadate (or $\mathrm{V}_{2} \mathrm{O}_{5}$ ), and various divalent carbonates (or oxides). Typical examples of preparation methods, including reactants and reaction conditions, are listed in Table 1.

Based on early results shown in Table $2, \mathrm{LiMVO}_{4}$ compounds have three different structures: (1) spinel, (2) olivine, and (3) phenacite. However, both $\mathrm{LiNiVO}_{4}$ and $\mathrm{LiCoVO}_{4}$ are shown to be inverse spinel according to our recent results from powder XRD data calculation [12]. Interestingly, the structures of both $\mathrm{LiMgVO}_{4}$ and $\mathrm{LiZnVO}_{4}$ can be converted from olivine or phenacite to spinel

TABLE 2

Types of Structures of $\mathrm{LiMVO}_{4}$ Compounds [17, 18, 24]

\begin{tabular}{ll}
\hline Structure & Compounds \\
\hline Spinel & $\mathrm{LiCuVO}_{4}, \mathrm{LiNiVO}_{4}^{*}, \mathrm{LiCoVO}_{4}^{*}$ \\
\hline Olivine & $\mathrm{LiMnVO}_{4}, \mathrm{LiCdVO}_{4}, \mathrm{LiMgVO}_{4}$ \\
\hline Phenacite & $\mathrm{LiBeVO}_{4}, \mathrm{LiZnVO}_{4}$ \\
\hline
\end{tabular}

${ }^{*}$ Both $\mathrm{LiNiVO}_{4}$ and $\mathrm{LiCoVO}_{4}$ are shown to be inverse spinel from our recent results [12] 
TABLE 3

Solid State Reactions for Preparing $\mathrm{LiNiVO}_{4}$

\begin{tabular}{|c|c|c|c|}
\hline $\begin{array}{c}\text { Starting Reactants } \\
\text { (mole ratio) }\end{array}$ & $\begin{array}{l}\text { Reaction } \\
\text { Condition } \\
\end{array}$ & $\begin{array}{c}\text { Reaction } \\
\text { Environment }\end{array}$ & Products \\
\hline $\begin{array}{l}\mathrm{LiNiO}_{2}+\mathrm{NH}_{4} \mathrm{VO}_{3} \\
\mathrm{LiNiO}_{2}+\mathrm{NH}_{4} \mathrm{VO}_{3} \\
\mathrm{LiNiO}_{2}+\mathrm{NH}_{4} \mathrm{VO}_{3} \\
2 \mathrm{LiNiO}_{2}+\mathrm{V}_{2} \mathrm{O}_{3} \\
2 \mathrm{LiNiO}_{2}+\mathrm{V}_{2} \mathrm{O}_{3} \\
2 \mathrm{LiNiO}_{2}+\mathrm{V}_{2} \mathrm{O}_{5} \\
2 \mathrm{LiNiO}_{2}+\mathrm{V}_{2} \mathrm{O}_{5} \\
\mathrm{Li}_{2} \mathrm{CO}_{3}+2 \mathrm{NiO}+\mathrm{V}_{2} \mathrm{O}_{5} \\
\mathrm{Li}_{2} \mathrm{CO}_{3}+2 \mathrm{NiO}_{2}+2 \mathrm{NH}_{4} \mathrm{VO}_{3} \\
\mathrm{LiNiO}_{2}+\mathrm{V}_{2} \mathrm{O}_{3} \\
\mathrm{LiNiO}_{2}+\mathrm{V}_{2} \mathrm{O}_{5}\end{array}$ & $\begin{array}{l}\text { (1) } \\
(1) \\
(1) \\
(1) \\
(1) \\
(1) \\
(1) \\
(2) \\
(3) \\
(4) \\
\text { (4) }\end{array}$ & $\begin{array}{l}\text { Argon } \\
\text { Ammonia } \\
\text { Air } \\
\text { Ammonia } \\
\text { Air } \\
\text { Argon } \\
\text { Air } \\
\text { Air } \\
\text { Air } \\
\text { Air } \\
\text { Air }\end{array}$ & $\begin{array}{l}\mathrm{LiNiVO}_{4}, \mathrm{Li}_{3} \mathrm{VO}_{4}, \mathrm{NiO}, \mathrm{Ni}, \mathrm{V}_{2} \mathrm{O}_{3} \\
\mathrm{LiVO}_{2}, \mathrm{Li}_{3} \mathrm{VO}_{4}, \mathrm{Ni}, \mathrm{V}_{2} \mathrm{O}_{3},{ }^{*} \\
\mathrm{LiNiVO}_{4}, \mathrm{Li}_{3} \mathrm{VO}_{4}, \mathrm{NiO} \\
\mathrm{LiVO}_{2}, \mathrm{Li}_{3} \mathrm{VO}_{4}, \mathrm{Ni}, \mathrm{V}_{2} \mathrm{O}_{4},{ }^{*} \\
\mathrm{LiNiVO}_{4} \\
\mathrm{LiNiVO}_{4}, \mathrm{Li}_{3} \mathrm{VO}_{4}, \mathrm{NiO}, \mathrm{V}_{2} \mathrm{O}_{3} \\
\mathrm{LiNiVO}_{4} \\
\mathrm{LiNiVO}_{4} \\
\mathrm{LiNiVO}_{4} \\
\mathrm{LiNiVO}_{4} \\
\mathrm{LiNiVO}_{4}\end{array}$ \\
\hline
\end{tabular}

${ }^{\ddagger}$ Reaction conditions: (1) $500^{\circ} \mathrm{C}, 4 \mathrm{~h} \& 800^{\circ} \mathrm{C}, 8 \mathrm{~h}$; (2) $600^{\circ} \mathrm{C}, 3$ days, (3) $730^{\circ} \mathrm{C}, 12 \mathrm{~h}$; (4) $700^{\circ} \mathrm{C}, 2 \mathrm{~h}$.

${ }^{*} \mathrm{LiNiVO}_{4}$ produced after reducing at $500^{\circ} \mathrm{C}$ for 4 hours.

by high-pressure modification $[16,18]$. Only compounds with spinel or spinel related structures will be discussed in this paper, because they are potential cathode materials for lithium secondary batteries.

Existing methods for preparing $\mathrm{LiNiVO}_{4}$ are not economical because of the long reaction times and hgh temperatures required. Bernier et al. [15] reacted $\mathrm{LiVO}_{3}$ and $\mathrm{NiCO}_{3}$ at $500^{\circ} \mathrm{C}$ for 7 days and Ito [25] reacted $\mathrm{LiVO}_{3}$ and $\mathrm{NiO}$ at $1000^{\circ} \mathrm{C}$

for 4 days.

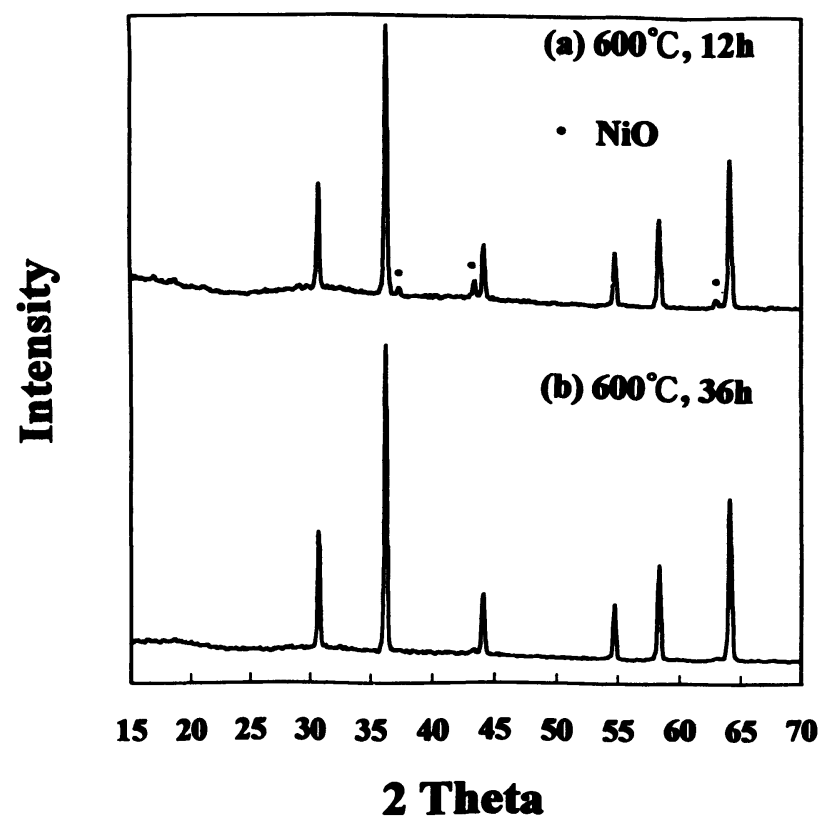

FIGURE 1 XRD Patterns of $\mathrm{LiNiVO}_{4}$ Prepared from the Reaction of $\mathrm{Li}_{2} \mathrm{CO}_{3}, \mathrm{NiO}$ and $\mathrm{V}_{2} \mathrm{O}_{5}$. 


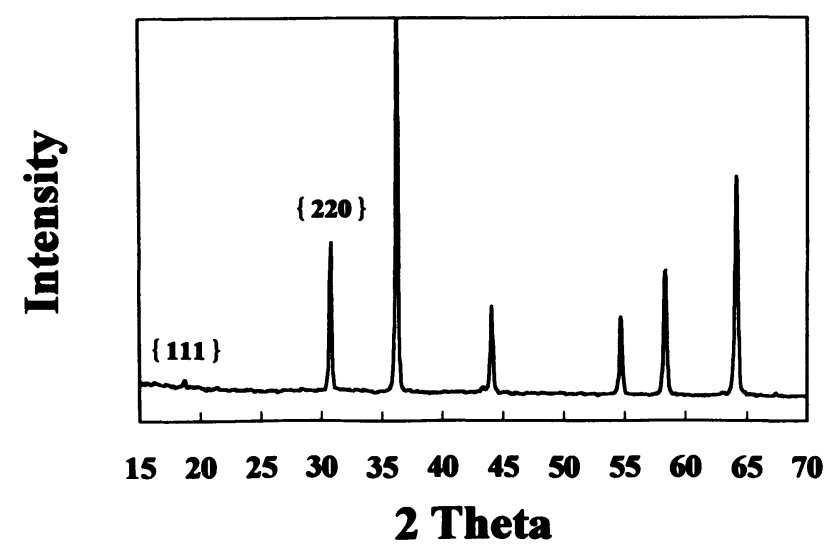

FIGURE 2 The XRD Pattern of $\mathrm{LiNiVO}_{4}$ Prepared from the Reaction of $\mathrm{Li}_{2} \mathrm{CO}_{3}, \mathrm{NiO}$ and $\mathrm{NH}_{4} \mathrm{VO}_{3}$.

To develop a new and more practical method, we carried out a series of solid state reactions using different starting materials in various gaseous atmospheres. The results are presented in Table 3 . The optimum preparation method of $\mathrm{LiNiVO}_{4}$ used an air reaction atmosphere and $\mathrm{LiNiO}_{2}$ and $\mathrm{V}_{2} \mathrm{O}_{3}$ or $\mathrm{V}_{2} \mathrm{O}_{5}$ as starting reactants. Pure $\mathrm{LiNiVO}_{4}$ can be obtained by reacting $\mathrm{LiNiO}_{2}$ and $\mathrm{V}_{2} \mathrm{O}_{3}$ or $\mathrm{V}_{2} \mathrm{O}_{5}$ at $700^{\circ} \mathrm{C}$ in 2 hours. In the majority of the reactions, small amounts of impurities such as $\mathrm{Li}_{3} \mathrm{VO}_{4}, \mathrm{NiO}, \mathrm{Ni}$, and $\mathrm{LiVO}_{2}$ were also produced. In an argon or ammonia atmosphere, such as when $\mathrm{NH}_{4} \mathrm{VO}_{3}$ is a starting reactant, $\mathrm{LiNiO}_{2}$ can further be reduced to nickel metal. The strongest $\mathrm{NiO}$ Bragg peaks confirmed by JCPDS data were near 16.2, 21.5, and 24.3 degrees. Figure 1 illustrates that these $\mathrm{NiO}$ peaks can be removed by extending reaction time from 12 hours to 36 hours at $600^{\circ} \mathrm{C}$ during the reaction of $\mathrm{Li}_{2} \mathrm{CO}_{3}, \mathrm{NiO}$ and $\mathrm{V}_{2} \mathrm{O}_{5}$. The XRD pattern of pure $\mathrm{LiNi}-\mathrm{VO}_{4}$ in Figure 2, obtained by reacting $\mathrm{Li}_{2} \mathrm{CO}_{3}, \mathrm{NiO}$ and $\mathrm{NH}_{4} \mathrm{VO}_{3}$ at $730^{\circ} \mathrm{C}$ for 12 hours, is identical to that of the product from the $2 \mathrm{LiNiO}_{2}$ and $\mathrm{V}_{2} \mathrm{O}_{5}$ reaction at $700^{\circ} \mathrm{C}$ for 2 hours.

Figures $3 a, 3 b$ and $3 c$ display the thermograviometric behavior of the $2 \mathrm{LiNiO}_{2}$ and $\mathrm{V}_{2} \mathrm{O}_{3}$ reaction, the $2 \mathrm{LiNiO}_{2}$ and $\mathrm{V}_{2} \mathrm{O}_{5}$ reaction, and the $\mathrm{Li}_{2} \mathrm{CO}_{3}, 2 \mathrm{NiCO}_{3}$ and $\mathrm{V}_{2} \mathrm{O}_{5}$ reaction in air, respectively. From $700^{\circ} \mathrm{C}$ to $950^{\circ} \mathrm{C}$, the weight of the specimen remained almost constant. Using XRD to characterize the TGA residue, we were able to confirm that $\mathrm{LiNiVO}_{4}$ was produced and conclude that $\mathrm{LiNiVO}_{4}$ can be prepared by reacting $2 \mathrm{LiNiO}_{2}$ and $\mathrm{V}_{2} \mathrm{O}_{3}$ or $\mathrm{V}_{2} \mathrm{O}_{5}$ in air around $700^{\circ} \mathrm{C}$. The isostructural compound $\mathrm{LiCoVO}_{4}$ was produced by reacting $2 \mathrm{LiCoO}_{2}$ with $\mathrm{V}_{2} \mathrm{O}_{3}$ or $\mathrm{V}_{2} \mathrm{O}_{5}$ at $700^{\circ} \mathrm{C}$ for only 1 hour in air. Both reactions required less than 2 hours. Because incomplete reactions occur at lower temperatures, the synthesis of these vanadates should be at above $650^{\circ} \mathrm{C}$. $\mathrm{LiCoVO}_{4}$ can also be prepared by reacting $\mathrm{Li}_{2} \mathrm{CO}_{3}, \mathrm{Co}_{3} \mathrm{O}_{4}$, and $\mathrm{V}_{2} \mathrm{O}_{5}$ at $800^{\circ} \mathrm{C}$ for 12 hours, the XRD pattern shown in Figure 4. Because of the relatively low reaction temperature and the much shorter reaction time, we can conclude that the reaction of $\mathrm{LiMO}_{2}$ (where $\mathrm{M}=\mathrm{Ni}$ or $\mathrm{Co}$ ) with $\mathrm{V}_{2} \mathrm{O}_{3}$ or $\mathrm{V}_{2} \mathrm{O}_{5}$ is a practical method for producing a large quantity of good quality $\mathrm{LiMVO}_{4}(\mathrm{M}=\mathrm{Ni}$ or $\mathrm{Co})$. 


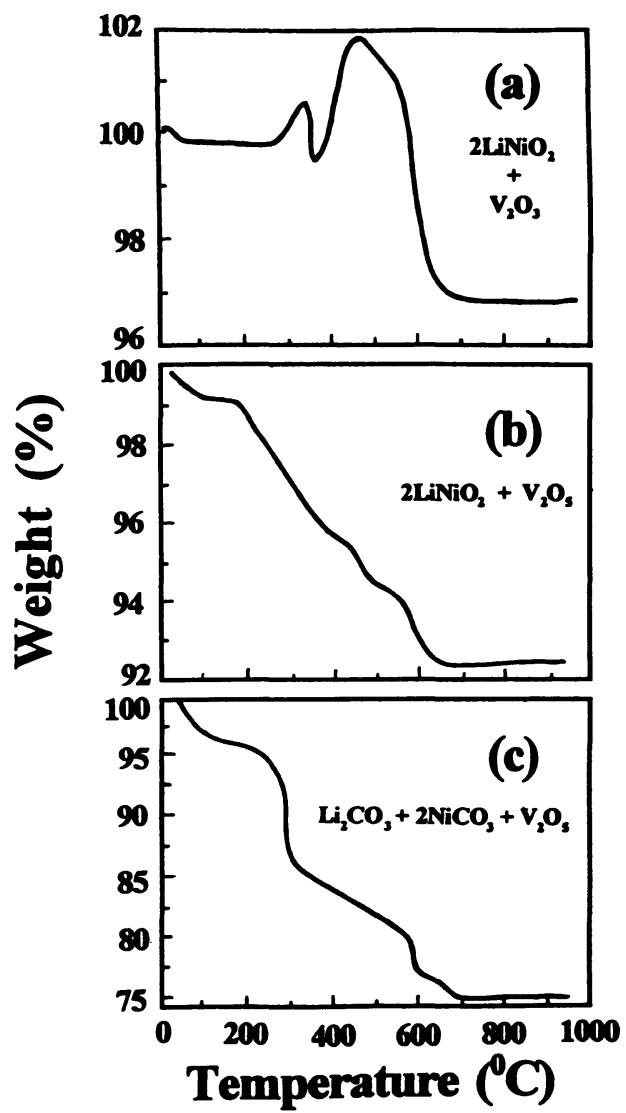

FIGURE 3 TGA Diagrams of Solid State Reactions in Air.

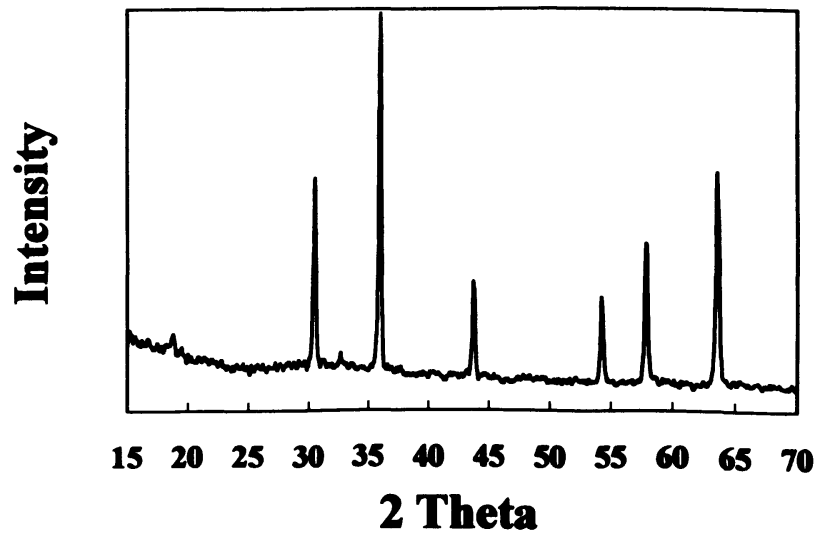

FIGURE 4 The XRD Pattern of $\mathrm{LiCoVO}_{4}$ Prepared from the Reaction of $\mathrm{Li}_{2} \mathrm{CO}_{3}, \mathrm{Co}_{3} \mathrm{O}_{4}$ and $\mathrm{NH}_{4} \mathrm{VO}_{3}$. 


\section{EFFECTS OF REACTANTS STOICHIOMETRY ON THE FORMATION OF LiNiVO 4}

The products of solid state reactions between $\mathrm{LiNiO}_{2}$ and $\mathrm{NH}_{4} \mathrm{VO}_{3}$ with various stoichiometry in ammonia were characterized [13]. The reactions took place under reductive conditions, first at $500^{\circ} \mathrm{C}$ for 4 hours and then at $650^{\circ} \mathrm{C}$ for 24 hours. In all cases, only nickel metal was produced and no $\mathrm{LiNiVO}_{4}$ was formed. When the reactant ratio of $\mathrm{LiNiO}_{2}$ to $\mathrm{NH}_{4} \mathrm{VO}_{3}$ was less than one, $\mathrm{V}_{2} \mathrm{O}_{3}$ and $\mathrm{LiVO}_{2}$ were the main products. When it was greater than one, $\mathrm{Li}_{3} \mathrm{VO}_{4}$ was the main product. When the mole ratios were one, nickel, $\mathrm{V}_{2} \mathrm{O}_{3}, \mathrm{LiVO}_{2}$, and $\mathrm{Li}_{3} \mathrm{VO}_{4}$ were produced. Because $\mathrm{NH}_{4} \mathrm{VO}_{3}$ did not seem to be an effective starting reactant, $\mathrm{V}_{2} \mathrm{O}_{3}$ and $\mathrm{V}_{2} \mathrm{O}_{5}$ were later used.

The products of solid state reactions between $\mathrm{LiNiO}_{2}$ and $\mathrm{V}_{2} \mathrm{O}_{3}$ in air, which took place first at $500^{\circ} \mathrm{C}$ for 4 hours and then at $800^{\circ} \mathrm{C}$ for 6 hours were also characterized [13]. When the ratio of $\mathrm{LiNiO}_{2}$ to $\mathrm{V}_{2} \mathrm{O}_{3}$ was less than two, a complicated mixture of $\mathrm{Li}_{3} \mathrm{VO}_{4}, \mathrm{NiV}_{2} \mathrm{O}_{7}$, and $\mathrm{Ni}_{3}\left(\mathrm{VO}_{4}\right)_{2}$ was formed. When the ratio was greater than two, $\mathrm{LiNiVO}_{4}$ was the main product with some impurities such as $\mathrm{Li}_{3} \mathrm{VO}_{4}$ and $\mathrm{NiO}$. When the ratio was equal to two, pure $\mathrm{LiNiVO}_{2}$ was produced. This finding was a major breakthrough in developing a preparation method for $\mathrm{LiNiVO}_{4}$.

\section{STRUCTURES OF LiMvO 4 COMPOUNDS ( $\mathrm{M}=\mathrm{Ni}, \mathrm{Co}, \mathrm{Cu}$ )}

There are two kinds of spinel for $\mathrm{AB}_{2} \mathrm{O}_{4}$ oxides: one is normal spinel and the other is inverse spinel. In normal spinel structure compounds, such as $\mathrm{LiMn}_{2} \mathrm{O}_{4}$ and $\mathrm{LiTi}_{2} \mathrm{O}_{4}$, oxygen atoms are in a closely packed cubic array with transition metal atoms residing in the interstices to form an octahedron with the six closest oxygen atoms. The lithium atoms also reside in interstices forming a tetrahedron with four neighboring oxygen atoms. The structural arrangement can be represented as $[\mathrm{A}]_{\text {tetra }}[\mathrm{B} 2]_{\text {octa }} \mathrm{O}_{4}$ and is depicted in Figure 5 .

The above distribution of atoms creates a three dimensional network of tunnels. Because $\mathrm{Li}$ atoms are located throughout and can diffuse through these tunnels, their presence is thought to be essential to the intercalation and deintercalation of lithium from these materials. These compounds can also react further with lithium to produce $\mathrm{Li}_{2} \mathrm{Ti}_{2} \mathrm{O}_{4}$ and $\mathrm{Li}_{2} \mathrm{Mn}_{2} \mathrm{O}_{4}$. If lithium is removed from $\mathrm{LiTi}_{2} \mathrm{O}_{4}$ and $\mathrm{LiMn}_{2} \mathrm{O}_{4}, \lambda-\mathrm{MnO}_{2}$ and $\mathrm{Li}_{1-x} \mathrm{Ti}_{2} \mathrm{O}_{4}$ are formed, respectively.

In inverse spinel compounds, the cations are arranged differently. In $\mathrm{LiNiVO}_{4}$, the $\mathrm{Li}$ and $\mathrm{Ni}$ atoms are thought to be equally and randomly distributed among octahedrally coordinated interstices and the $\mathrm{V}$ atoms distributed among tetrahedrally coordinated interstices. The above structural arrangement can be represented as $[\mathrm{B}]_{\text {tetra }}[\mathrm{AB}]_{\text {octa }} \mathrm{O}_{4}$. In relation to $\mathrm{LiMn}_{2} \mathrm{O}_{4}$, the $\mathrm{Li}$ and $\mathrm{Ni}$ atoms correspond to the $2 \mathrm{Mn}$ atoms and the $\mathrm{V}$ atom to the $\mathrm{Li}$ atom.

Unlike $\mathrm{LiMn}_{2} \mathrm{O}_{4}$, there are no obvious tunnels for mobile $\mathrm{Li}$ atoms to move through, so it is surprising that intercalation takes place. However, using in situ 

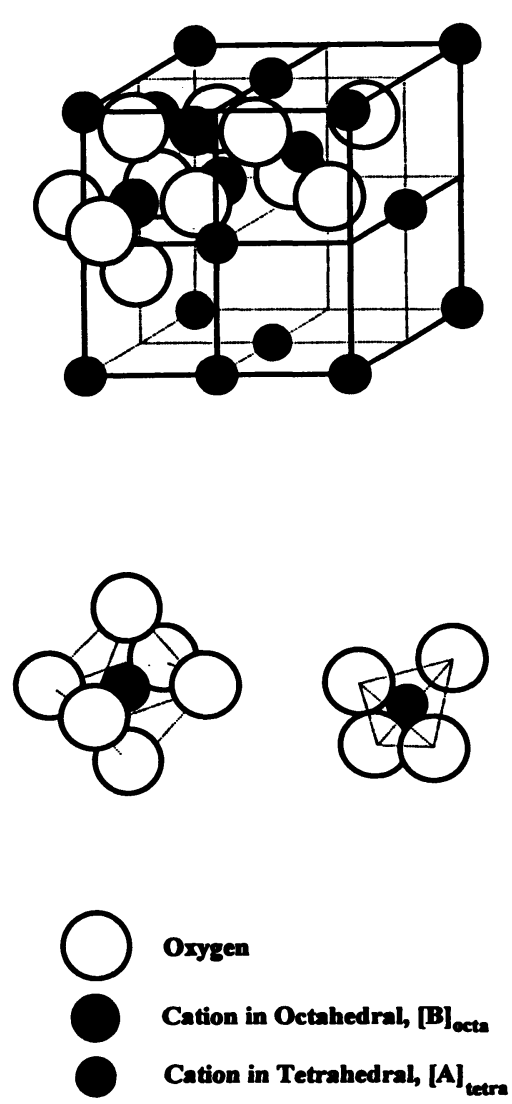

FIGURE 5 Spinel Structure of $\mathrm{AB}_{2} \mathrm{O}_{4}$.

diffraction (XRD), we have shown that lithium can be removed from $\mathrm{LiNiVO}_{4}$ and reversibly inserted again [12]. The intercalation/deintercalation takes place at a plateau near $4.8 \mathrm{~V}$ in $\mathrm{Li} / \mathrm{LiNiVO}_{4}$ cells [12]. To our knowledge, this is the $\mathrm{Li}$ intercalation reaction with the highest voltage. Although $\mathrm{LiCoVO}_{4}$ is an isostructural compound that also demonstrates reversible lithium intercalation, its voltage is only around $4.2 \mathrm{~V}$ versus $\mathrm{Li}$. We do not yet understand why the voltage of $\mathrm{Li} / \mathrm{LiNiVO}_{4}$ cells is so high. It may be partly attributed to the fact that lithium atoms are octahedrally surrounded by six oxygen atoms in an inverse spinel structure. It is more difficult to remove a $\mathrm{Li}$ atom from an octahedron of six oxygen atoms than from a tetrahedron of four oxygen atoms such as in a spinel structure.

The XRD patterns and JCPDS data were identical for both $\mathrm{LiNiVO}_{4}$ and $\mathrm{LiCoVO}_{4}$, which had been prepared using the above method. The inverse spinel structure is evident because the $\{220\}$ peak is more intense that the $\{111\}$ peak, the opposite of what happens with normal spinel compounds. Transition metal atoms on the tetrahedrally coordinated interstices cause an increase in the $\{220\}$ peak at the expense of the $\{111\}$ peak. Our SEM results indicate that individual particles of 


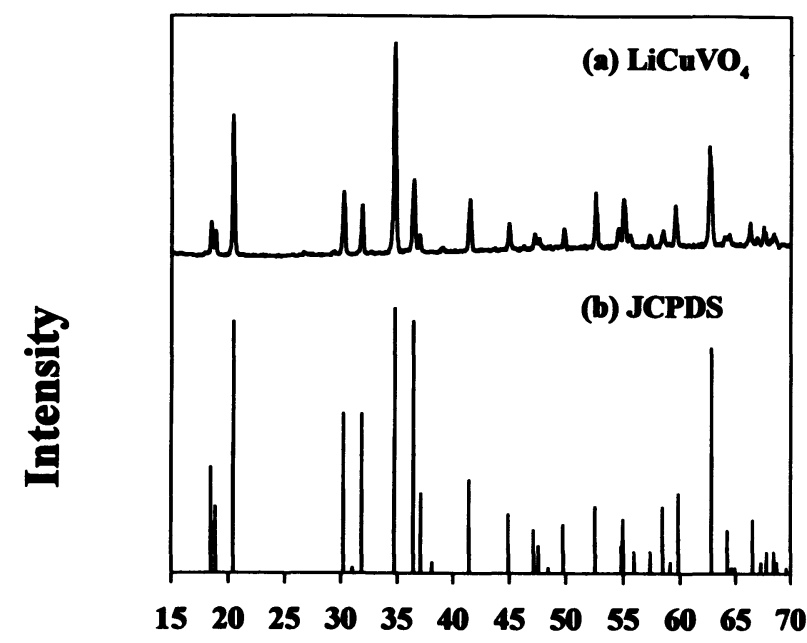

\section{Theta}

FIGURE 6 The XRD Pattern of $\mathrm{LiCuVO}_{4}$ Prepared from the Reaction of $\mathrm{LiVO}_{3}$ and $\mathrm{CuO}$.

$\mathrm{LiNiVO}_{4}$ powders are in the shape of an octahedron and well-formed crystallites of approximately $20 \mu \mathrm{m}$ [13].

Although the measured powder diffraction profile for $\mathrm{LiNiVO}_{4}$ is very close to a calculated pattern [12], assuming the inverse spinel structure suggested in reference [26], it is not close enough to completely understand the structure of this compound. Further structural analysis using neutral diffraction and ESCA is currently under way.

In the past, $\mathrm{LiNiVO}_{4}, \mathrm{LiCoVO}_{4}$ and $\mathrm{LiCuVO}_{4}$ were all considered to have a spinel structure $[14,15]$. From the above discussion, $\mathrm{LiNiVO}_{4}$ and $\mathrm{LiCoVO}_{4}$ are shown to possess an inverse spinel structure. Figure 6 displays the $\mathrm{X}$-ray diffraction pattern of $\mathrm{LiCuVO}_{4}$ prepared from the reaction of $\mathrm{LiVO}_{3}$ and $\mathrm{CuO}$ at $600^{\circ} \mathrm{C}$ for 36 hours. The pattern is identical to that of a JCPDS sample of spinel $\mathrm{LiCuVO}_{4}$ but very different from that of $\mathrm{LiNiVO}_{4}$ or $\mathrm{LiCoVO}_{4}$ shown in Figure 2 or Figure 5 . Notably, the $\{220\}$ peak is not more intense than the $\{111\}$ peak, implying that $\mathrm{LiCuVO}_{4}$ does not possess an inverse spinel structure. However, a new refinement of the room-temperature structure of $\mathrm{LiCuVO}_{4}$ [27] indicates that $\mathrm{LiCuVO}_{4}$ is an orthorhombic distortion of the cubic spinel structure, with $\mathrm{V}^{5+}$ ions on tetrahedral sites and $\mathrm{Li}^{+}$and $\mathrm{Cu}^{2+}$ ions ordered among octahedral sites. The orthorhombic distortion is caused by the one dimensional ordering of the lithium and copper ions [28]. Interestingly, the nature of the disorder in $\mathrm{LiCuVO}_{4}$ is similar to $\mathrm{Li}^{+}$and $\mathrm{Ni}^{2+}$ or $\mathrm{Co}^{2+}$ ions in the octahedral cation sublattice of $\mathrm{LiNiVO}_{4}$ or $\mathrm{LiCoVO}_{4}$, respectively. Lithiated $\mathrm{Li}_{1+x} \mathrm{CuVO}_{4}$, a cathode candidate for secondary lithium batteries, is electrochemically reversible in the range of $0<x<1.5$ [22]. 


\section{LINIVO 4 AS A HIGH VOLTAGE CATHODE MATERIAL FOR LITHIUM CELLS}

Since both $\mathrm{LiNiVO}_{4}$ and $\mathrm{LiCoVO}_{4}$ are not moisture sensitive, they can be handled under ambient atmosphere. To evaluate $\mathrm{LiNiVO}_{4}$ as a cathode material, we tested the performance of 2325 coin-type lithium cells with $125 \mu \mathrm{m}$ thick $\mathrm{Li}$ metal foil anodes, Celgard 2502 microporous polypropylene separators, and electrolytes of $1 \mathrm{M}$ solution of $\mathrm{LiBF}_{4}$ dissolved in a $66 / 17 / 17$ volume percent mixture of DMC, PC, and EC, respectively. The electrolyte solution was proposed to be oxidation resistant in the patent literature [29].

The $\mathrm{Li} / \mathrm{LiNiVO}_{4}$ test cells displayed a very high voltage of $4.8 \mathrm{~V}$, reasonable capacity, and reasonable rate capability. Figure 7 shows a diagram of voltage versus time for a $\mathrm{Li} / \mathrm{LiNiVO}_{4}$ coin cell which was cycled between 3.0 and $4.9 \mathrm{~V}$. Cell capacity diminished after the first charge and was much smaller than the theoretical capacity $(148 \mathrm{mAh} / \mathrm{g})$ expected from the complete removal of $\mathrm{Li}$ from $\mathrm{LiNiVO}_{4}$. However, the discharge capacity being on the low end of achievable capacity was probably caused by the problem of electrolyte oxidation occurring under these conditions.

Similar $\mathrm{Li} / \mathrm{LiCoVO}_{4}$ coin cells cycled between 3.0 and $4.5 \mathrm{~V}$ demonstrated better cycle life (Figure 8). For reasons not yet known, the voltage was much lower than the $\mathrm{Li} / \mathrm{LiNiVO}_{4}$ cell. The reversible capacity was only $40 \mathrm{mAh} / \mathrm{g}$ and the discharge capacity failed to increase when the cell was charged to $4.9 \mathrm{~V}$.

Some important lithiated transition metal oxides and sulfides and their approximate working voltages with respect to the lithium metal electrode are shown in Figure 9. Other potential anode materials such as lithiated graphite, lithium aluminum alloy, and lithium silicon alloy are also included for comparison and application. For instance, the combination of a 4-volt cathode material and natural graphite gives a lithium-ion secondary battery. Notably, both $\mathrm{LiNiVO}_{4}$ and $\mathrm{LiCoVO}_{4}$ are possible for 4-volt cathode candidates for lithium ion batteries.

The voltage range of the individual cathode materials in Figure 9 depends upon lithiation depth, $x$, or the number of reacting lithium atoms. $\mathrm{LiCuVO}_{4}$ shows a lower voltage but a larger extent of lithium insertion than the nickel and cobalt

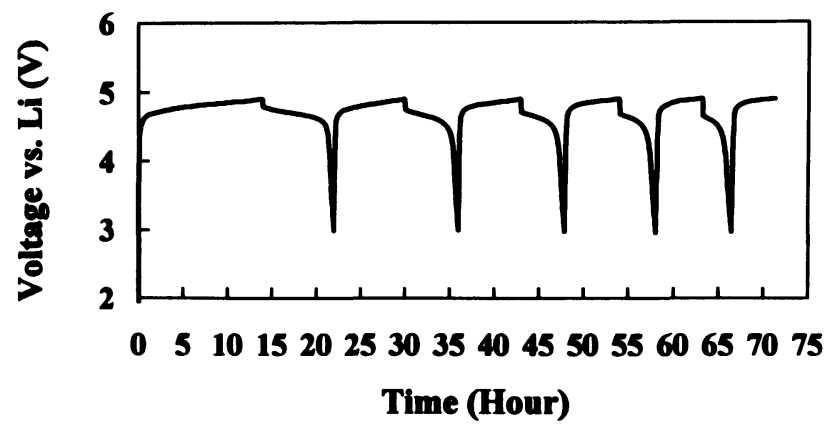

FIGURE 7 Voltage versus Time for a $\mathrm{Li} / \mathrm{LiNiVO}_{4}$ Cell 


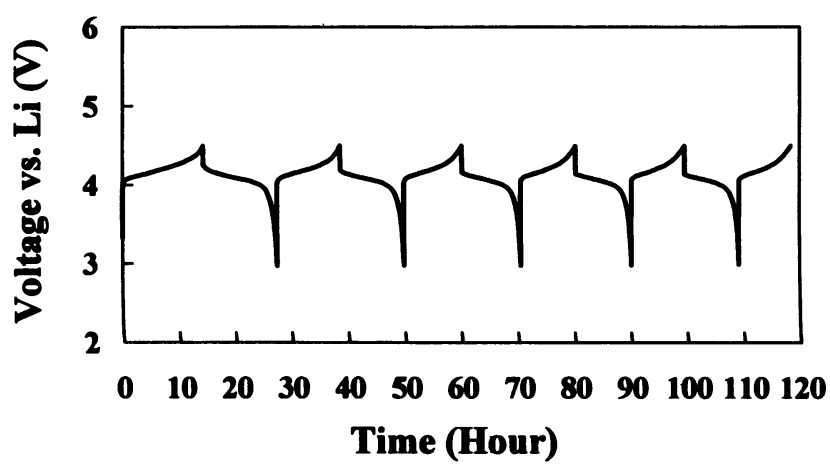

FIGURE 8 Voltage versus Time for a $\mathrm{Li} / \mathrm{LiCoVO}_{4}$ Cell

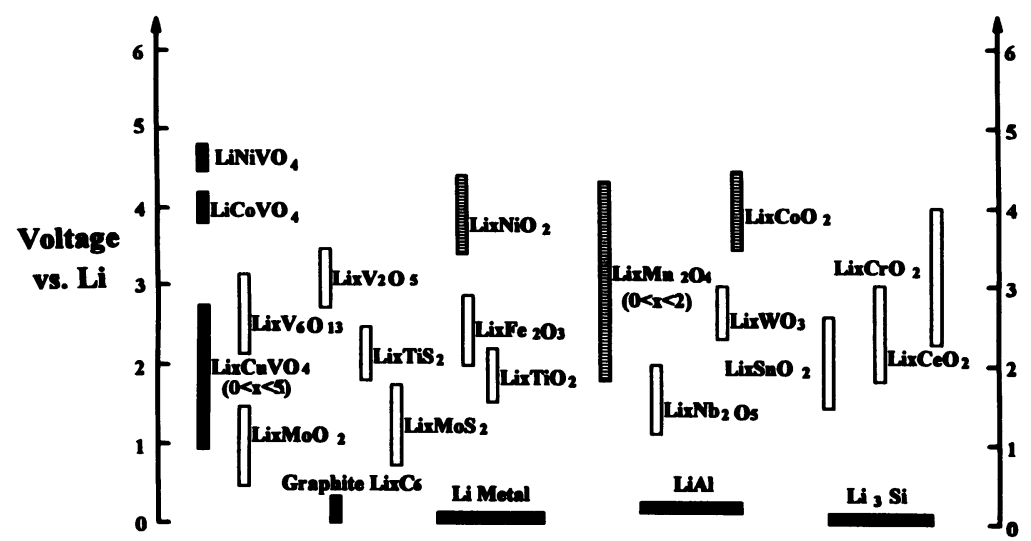

FIGURE 9 Approximate Working Voltage of Lithiated Transition Metal Oxides and Sulfides.

vanadates. The lithiation depth for $\mathrm{LiCuVO}_{4}$ can go as high as $x=5$ [22]. The voltage range for both $\mathrm{LiNiVO}_{4}$ and $\mathrm{LiCoVO}_{4}$ is small and the exact $x$ range for both vanadates has not yet been determined. Nevertheless, $\mathrm{LiNiVO}_{4}$ can discharge at $4.8 \mathrm{~V}$ vs. $\mathrm{Li}$, the highest voltage among all known cathode materials. Based on in situ x-ray cell results [12], the $\mathrm{LiNiVO}_{4}$ structure, is not destroyed during charging to $5.3 \mathrm{~V}$ and lithium atoms in $\mathrm{LiNiVO}_{4}$ can be reversibly extracted and reinserted near $4.8 \mathrm{~V}$ versus Li metal.

\section{CONCLUSION}

In the area of battery research, many studies have been done on spinel compounds such as $\mathrm{LiMn}_{2} \mathrm{O}_{4}$, which has already been successfully used as a cathode material in the $\mathrm{C} / \mathrm{Li}_{1+x} \mathrm{Mn}_{2} \mathrm{O}_{4}$ lithium ion battery. In contrast, there have been relatively few detailed studies on inverse spinel compounds, but our results show that further research may be very promising. The development of a commercially viable cell poses a challenge for the near future. For example, a great deal more must be learned about the structure of this material and better electrolytes with oxidation 
resistance of at least 5 volts must be developed. Indeed, $\mathrm{LiNiVO}_{4}$ may be a prime cathode material for future higher voltage cells, especially since $\mathrm{LiNiVO}_{4}$ can now be prepared in a much faster and more economical way than in the past.

\section{ACKNOWLEDGMENT}

The author would like to acknowledge the work of $\mathrm{Dr}$. Wu $\mathrm{Li}$ in performing the in-situ XRD cell measurements and the collaboration of Professor J. R. Dahn (Simon Fraser University, B. C., Canada) in using his XRD and coin-cell testing facilities.

\section{REFERENCES}

1. T. Nagaura and T. Tozawa, Progress in Batteries \& Solar Cells, 9, 20 (1990).

2. M.S. Whittingham, J. Electrochem. Soc., 123, 315 (1976).

3. M.S. Whittingham, Progress in Solid State Chem., 12, 41 (1978).

4. A.J. Jacobson, R.R. Chianelli and M.S. Whittingham, J. Electrochem. Soc., 126, 2277 (1979).

5. M.S. Whittingham and M.B. Dines, J. Electrochem. Soc., 124; 1388 (1977).

6. L. Campanella and G. Pistoia, J. Electrochem. Soc., 118, 1905 (1971).

7. J. Broadhead and F.A. Trumbore, Electrochem. Soc. Ext. Abstr., 73-1, 445 (1973).

8. D.W. Murphy and F.A. Trumbore, J. Electrochem. Soc., 123, 960 (1976).

9. F.W. Dampier, J. Electrochem. Soc., 121, 656 (1974).

10. D.W. Murphy, P.A. Christian, F.J. Di Salvo and J. N. Carides, J. Electrochem. Soc., 126, 497 (1979).

11. C.R. Walk and J.S. Gore, Electrochem. Soc. Ext. Abstr., 75-1, 60 (1975).

12. G.T.K. Fey, W. Li and J.R. Dahn, J. Electrochem. Soc., 141, 2279 (1994).

13. G.T.K. Fey and W.B. Perng, J. Power Sources, To be published.

14. A. Durif, J.C. Joubert and J.C. Grenier, Compt. Rend. Acad. Sci. (Paris), 260, 2472 (1965).

15. J.C. Bernier, P. Poix and A. Michel, Compt. Rend. Acad. Sci. (Paris), 253, 1578 (1961).

16. G. Blasse, J. Inorg. Nucl. Chem., 25, 136 (1963).

17. M. Th. Paques-Ledent and P. Tarte, Spectrochimica Acta, 30A, 673 (1974).

18. G. Blasse, Philips Res. Rept. Suppl. No. 3 (1964).

19. J. Preudhomme and P. Tarte, Spectrochimica Acta, 28A, 69 (1972).

20. L.L.Y. Chang and F.Y. Wang, J. Amer. Cera. Soc., 71, 689 (1988).

21. W.B. Perng, Master Thesis, National Central University, Taiwan, R.O.C. (1993).

22. R. Kanno, Y. Takeda, M. Hasegawa, Y. Kawamoto and O. Yamamoto, J. Solid State Chem., 94, 319 (1991).

23. M.M. Aslanukova, A.M. Khubiev, and E.G. Semin, J. Appl. Chem. U.S.S.R., 53, 1880 (1980).

24. R. Kanno, Y. Kawamoto, Y. Takeda, M. Hasegawa and O. Yamamoto, Solid State Ionics, 40/41, 576 (1980).

25. Y. Ito, Nippon Kagaku Kaishi, 111, 1483 (1979).

26. J.C. Bernier, P. Poix, and A. Michel, Bull. Soc. Chim. France, 1661 (1963).

27. M.A. Lafontaine, M. Leblanc and G. Ferey, Acta Cryst., C45, 1205 (1989).

28. R. Kanno, Y. Kawamoto, Y. Takeda, M. Hasegawa, O. Yamamoto, and N. Kinomura, J. Solid State Chem., 96, 397 (1992).

29. D. Guyomard and J.M. Tarascon, U.S. Pat. 5.192,629 (1993). 

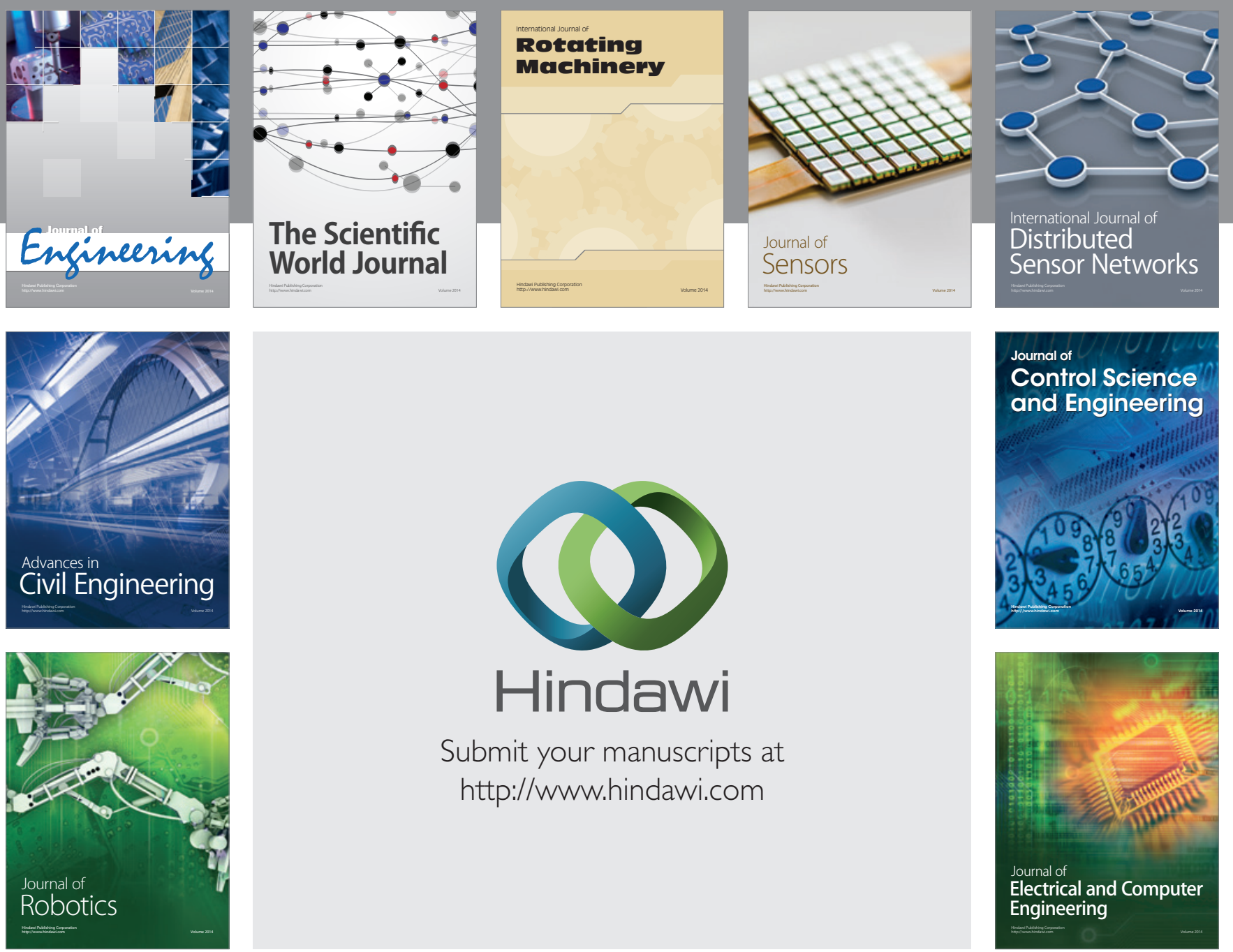

Submit your manuscripts at

http://www.hindawi.com
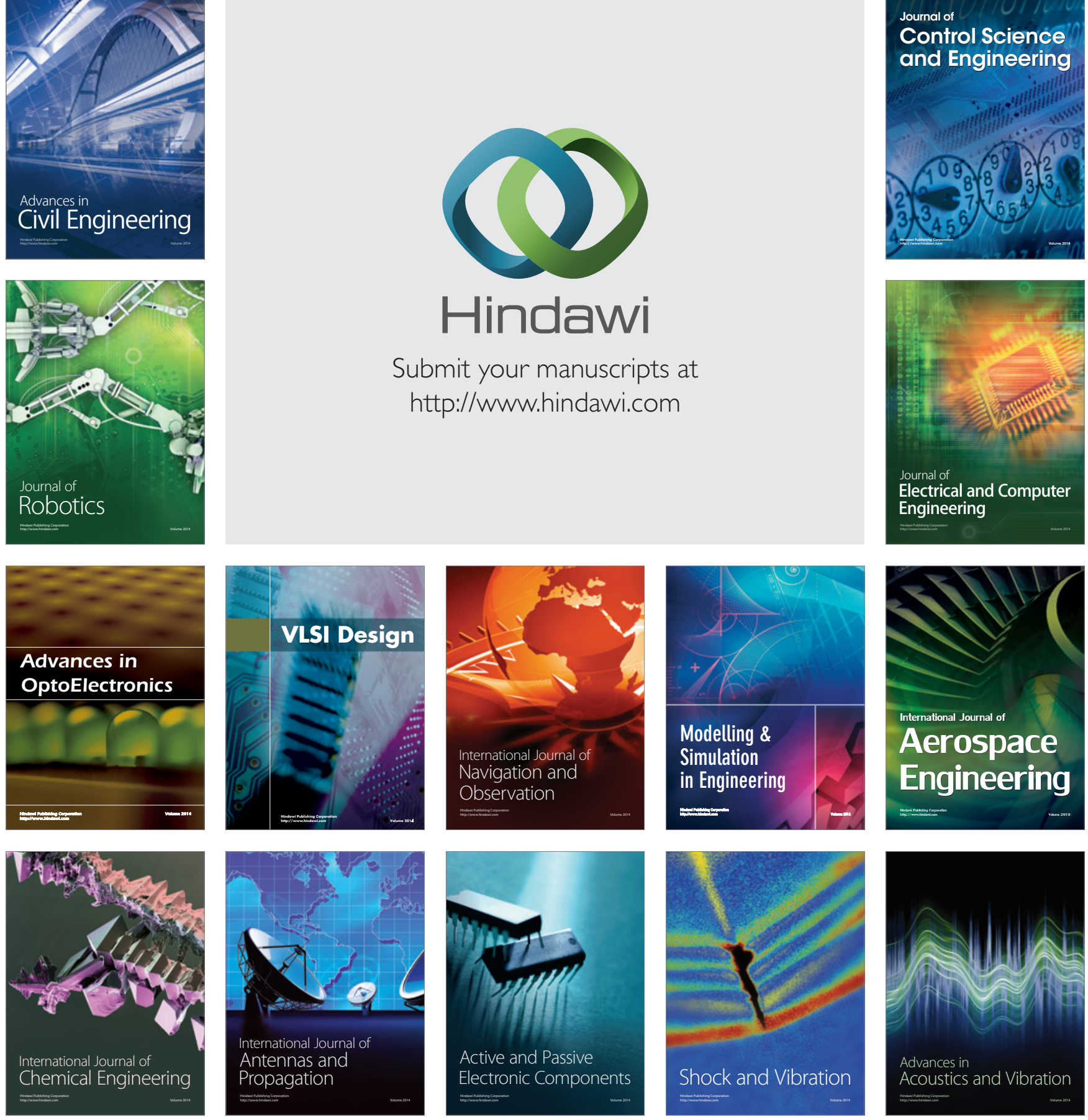